\title{
Initial Plant Growth in Sand Mine Spoil Amended with Organic Materials ${ }^{\circ}$
}

\author{
Todd A. Aschenbach and Mitchell Poling
}

\begin{abstract}
Sand dunes in the Great Lakes Basin are ecologically and economically important. One economic value of sand dunes is sand mining. However, sand mining activities reduce soil quality which represents an impediment to reclamation efforts. Soil quality improvements followed by revegetation may be necessary for successful reclamation. This study evaluates the germination and initial growth of two legume species, wild lupine (Lupinus perennis) and Illinois bundleflower (Desmanthus illinoensis), and two warm-season grass species, Indian grass (Sorghastrum nutans) and little bluestem (Schizachyrium scoparium), in the presence of three soil amendments (coco peat, municipal sewage sludge, and sphagnum peat moss) added to spoil from a local sand mine. Species were grown in pots and propagated under greenhouse conditions. Our results indicate that lupine and Illinois bundleflower exhibited the greatest germination and growth and are recommended as potential candidates for the reclamation of sand mines. Indian grass and little bluestem exhibited low rates of germination and growth. Among spoil amendments, we recommend coco peat based on germination and root, shoot, and total biomass results. Peat moss also exhibited increased rates of germination and growth. We did not observe any germination success for seeds sown in sewage sludge amended spoil. The lack of germination in the sewage sludge amendment may be due to a combination of unfavorable abiotic and biotic soil conditions such as electrical conductivity, $\mathrm{pH}$, or soil microbial activity. Our results are helpful in determining which species and amendment combinations are useful candidates for revegetating former sand mines or similar habitats.
\end{abstract}

Keywords: coco peat, Desmanthus, Lupinus, sand mine reclamation, soil amendments, spoil

The he Great Lakes Basin, USA exhibits the greatest extent of surface freshwater and the largest collection of freshwater sand dunes in the world (Albert 2000). Within the basin, the State of Michigan has the greatest length of Great Lakes shoreline, with an estimated $4912 \mathrm{~km}$ of $15,670 \mathrm{~km}$ total (US Lake Survey 1952, Cole et al. 1998). The state also contains extensive freshwater dune ecosystems. These dune ecosystems are vital to a diverse collection of flora and fauna, some of which are rare, threatened, or endangered. Endemic plant species include the Pitcher's thistle (Cirsium pitcheri), dwarf lake iris (Iris lacustris), Houghton's goldenrod (Oligoneuron houghtonii), and Lake Huron tansy (Tanacetum bipinnatum ssp. huronense). Rare birds include the piping plover (Charadrius melodus; Albert 2000, Hamzé and Jolls 2000, Kost et al. 2010).

Sand dunes are also economically important to the United States and the global economy. Mined sand is

(2) This open access article is distributed under the terms of the CC-BYNC-ND license (http://creativecommons.org/licenses/by-nc-nd/3.0) and is freely available online at: http://er.uwpress.org

Ecological Restoration Vol. 33, No. 2, 2015

ISSN 1522-4740 E-ISSN 1543-4079

(C2015 by the Board of Regents of the University of Wisconsin System. primarily used for road and building construction, glass production, foundry molds, and hydraulic fracturing (USGS 2013). In the United States, sand and gravel mining constitutes $48 \%$ of all mining operations (USDHHS 2008); 805 million metric tons of sand and gravel were mined in 2009 at a value of \$US 6.8 billion (USGS 2010). The United States has been a leading producer of industrial sand, constituting $35 \%$ of global production. Within the US, Michigan is one of the leading sand and gravel producers in the nation, extracting 36 million metric tons in 2009 at a value of \$US 203 million (USGS 2009).

Sand mining processes severely degrade the affected ecosystems, causing losses in biodiversity and negatively impacting soil structure and composition (Bowles et al. 1990, Lake Michigan Federation 1999, Cummings et al. 2005). During mining, vegetation is removed from the site which decreases native plant diversity and cover and increases the chance of non-native species invasion. This can result in the establishment of a less biologically diverse ecosystem after the cessation of mining activities (Gaffney and Dickerson 1987, Enright and Lamont 1992, Lozon and MacIsaac 1997). Loss of vegetation can also result in increased soil erosion that removes some or all of the pre-disturbance seed bank and results in decreased soil 
organic matter, nutrients, soil microbes, and water holding capacity (Reeder and Sabey 1987, Prosser and Roseby 1995, Thornton et al. 2006, Larney and Angers 2012). These factors, coupled with seasonal drought and soil compaction due to mining activities greatly inhibit plant establishment (Benigno et al. 2013).

The degradation of the ecosystem, and soil resources in particular, impedes the natural succession and reestablishment of plant species. Some native dune species will inhabit the previously mined area, but the rate of colonization and establishment is drastically slow (Maun and Krajnk 1989, Bowles et al. 1990). Degradation also creates colonization opportunities for invasive plant species (Lozon and MacIsaac 1997). Successful reclamation of degraded sand dunes requires both soil quality improvements and revegetation efforts (Pichtel et al. 1994, Choi and Pavlovic 1998, Wali 1999, Cummings et al. 2005, Larney and Angers 2012).

Due to the ecological importance of sand dunes combined with their slow natural recovery following sand mining activities, active sand mine reclamation is required by federal, state, and provincial law throughout the Great Lakes Basin. Former sand mines must be ecologically restored to reflect pre-disturbance characteristics such as vegetation cover, topography, and topsoil depth (see Chapter NR 135, Wisconsin Administrative Code; Michigan Natural Resources and Protection Act 451 of 1994; Ontario Mining Act of 1990). Although sand mine reclamation is legally mandated, there is relatively little guidance in the literature afforded to restoration practitioners on how to effectively and efficiently restore former sand mines.

A by-product of sand mining that is used in sand mine restoration is spoil. Spoil is a mixture of unwanted sand grain sizes and small amounts of impurities, such as organic matter and is typically spread over the disturbed areas prior to restoration of a sand mine site (A. Slater, Standard Sand Co., Fairmont Minerals, Grand Haven, MI, pers. comm.). Previous studies have found that the addition of amendments to sand mine spoil greatly improves the soil quality and the success of revegetation efforts (Maun and Krajnyk 1989, Benigno et al. 2013). Amendments such as fertilizer, municipal sewage sludge ("biosolids"), paper de-inking sludge, compost, peat moss, coconut fiber, and woody debris are known to improve soil structure, hydrological balance, and nutrient content (Maun and Krajnyk 1989, Wester et al. 1991, Choi and Pavlovic 1998, Fierro et al. 1999, Khayyat et al. 2007, Awang et al. 2009, Curtis and Claassen 2009).

Native warm-season grasses and legumes are most commonly recommended for revegetating former sand mine sites. These plant functional groups are beneficial because of their ability to tolerate the hot, dry, and infertile conditions of post-mine sites (Gaffney and Dickerson 1987, MacDonald et al. 2003, Li et al. 2013). Legumes also exhibit the ability to fix atmospheric nitrogen, which is often lacking in post-mine soils (Gaffney and Dickerson 1987, Palmgren 2000). Soil nitrogen can aid in the germination and growth of surrounding plants and promote the establishment of a more complex plant community (Jefferies et al. 1981, Tilman 1988, Callaway 1995, Callaway and Walker 1997). However, the beneficial impacts may depend on soil and climate characteristics and the composition of particular legumes and non-legumes in a plant community (Spehn et al. 2002).

Research by Aschenbach and others (2012) investigated the initial growth of legumes and warm-season grasses in sand mine spoil amended with peat moss and inorganic fertilizer. Results indicated that peat moss had the greatest positive impact on germination and growth. However, acquiring peat moss through peat mining results in the destruction of peat bogs (Rochefort 2000, Mitchell et al. 2002, Suret et al. 2002). Inorganic fertilizer also had a positive effect on plant growth. The study presented here is an extension of this earlier research and investigates alternatives to peat and fertilizer spoil amendments.

Here, we evaluate the germination and growth of native plant species grown on a combination of sand mine spoil and soil amendments under greenhouse conditions. Plant species include two legumes: wild lupine (Lupinus perennis) and Illinois bundleflower (Desmanthus illinoensis), and two warm-season grasses: Indian grass (Sorghastrum nutans) and little bluestem (Schizachyrium scoparium). Species were chosen based on their ability to reduce soil erosion, increase soil nitrogen, and their reported success in previous mine restoration efforts (Jefferies et al. 1981, Gaffney and Dickerson 1987, Palmgren 2000).

Each soil amendment was chosen based on its demonstrated ability to improve plant growth in a successional or restoration context (Carson and Barrett 1988, Haering et al. 2000, MacDonald et al. 2003, Carabassa et al. 2010, Aschenbach et al. 2012, Li et al. 2013). Three different soil amendments were used in this study: municipal sewage sludge, sphagnum peat moss, and coconut coir ("coco peat"). Commercial availability of both plant species and spoil amendments was also considered when choosing species and amendments for this study.

Our objectives were to: 1 ) determine which of the evaluated species exhibit the greatest germination success and biomass accumulation; and 2) identify which spoil amendments, if any, positively affect seed germination and initial plant growth. This study helps in identifying species that can be used for revegetation efforts of former sand mines at a regional scale and begins to provide insight on which plant functional groups (i.e., legumes, warm-season grasses) and spoil amendments will be most beneficial for sand mine reclamation at a global scale. 


\section{Methods}

\section{Study Species}

Wild lupine, Illinois bundleflower, Indian grass, and little bluestem were evaluated for their potential use in sand mine reclamation. All species are adapted for growth in well-drained, medium to dry, infertile soils including sands, and are native to the Great Lakes Basin (USDA-NRCS 2014). These species are also commercially available from native plant nurseries and seed suppliers. Little bluestem and wild lupine are found locally in sand dunes or similar habitats (e.g., sand prairies), while Illinois bundleflower and Indian grass are not characteristic species in these habitats (Kost et al. 2010). Therefore, Illinois bundleflower and Indian grass would not satisfy restoration goals where only species that are characteristic of sand dune plant communities are acceptable, but might be valuable species from a reclamation viewpoint.

\section{Spoil}

We obtained sand mine spoil from the Standard Sand Co., Fairmont Minerals, Grand Haven, MI. We obtained secondary sewage sludge from the Grandville Clean Water Plant, Grandville, MI. We measured spoil organic matter using the Loss-On-Ignition method; 10 samples of each spoil treatment were ignited in a muffle furnace for $5 \mathrm{~h}$ at $500^{\circ} \mathrm{C}$ (Nelson and Sommers 1996). Mean organic matter in non-amended spoil (control) was $0.4 \%, 7.3 \%$ in spoil that contained peat, $4.0 \%$ in spoil that contained coco peat, and $2.1 \%$ in spoil that contained sludge.

Spoil $\mathrm{pH}$ was determined from 10 samples of a 1:1 spoil:deionized water solution for each spoil treatment using a mini lab pH meter (IQ Scientific Instruments Inc., Carlsbad, CA). Mean spoil $\mathrm{pH}$ in non-amended spoil was $7.4\left(\mathrm{H}+\right.$ conc. $\left.=4.0 \times 10^{-8}\right), 5.3\left(\mathrm{H}+\right.$ conc. $\left.=5.0 \times 10^{-6}\right)$ in spoil that contained peat, $6.4\left(\mathrm{H}+\right.$ conc. $\left.=4.0 \times 10^{-7}\right)$ in spoil that contained coco peat, and $4.9(\mathrm{H}+$ conc. $=1.3 \times$ $10^{-5}$ ) in spoil that contained sludge.

Spoil nitrate $\left(\mathrm{NO}_{3}^{-}\right)$was determined from 10 samples for each spoil treatment via ion chromatography (DIONEX DX 500 Chromatography System, Sunnyvale, CA) of an extraction from $15.0 \mathrm{~g}$ of spoil mixed with $100 \mathrm{~mL}$ of $2 \mathrm{M} \mathrm{KCl}$ (Binkley and Vitousek 1991). Mean nitrate in non-amended spoil was $5.13 \mathrm{mg} / \mathrm{kg}, 4.60 \mathrm{mg} / \mathrm{kg}$ in spoil amended with peat, $1.87 \mathrm{mg} / \mathrm{kg}$ in spoil amended with coco peat, and $341.87 \mathrm{mg} / \mathrm{kg}$ in spoil amended with sludge.

Electrical Conductivity $\left(\mathrm{EC}_{\mathrm{e}}\right)$ was estimated from 6 samples of saturated paste for each spoil treatment using a $50 \mathrm{~cm}^{3}$ "Bureau of Soils" cup (Rhoades 1996). Mean EC in non-amended spoil was $4.85 \mathrm{dS} / \mathrm{m} ; 1.75 \mathrm{dS} / \mathrm{m}$ in spoil amended with peat, $3.03 \mathrm{dS} / \mathrm{m}$ in spoil amended with coco peat, and $27.83 \mathrm{dS} / \mathrm{m}$ in spoil amended with sludge.

\section{Experimental Design}

Growth from seed of each species was evaluated using 4 sand spoil treatments: spoil only (control), peat, coco peat, and sewage sludge. Spoil and amendments were mixed and added to sterilized $90 \mathrm{~cm}^{2} \times 8 \mathrm{~cm}$-deep square pots; Each pot contained a piece of shade cloth at the bottom to prevent spoil loss; Total volume of spoil and amendments in each pot was $400 \mathrm{~mL}$. The control treatment consisted of $400 \mathrm{~mL}$ of spoil only. The peat treatment consisted of $200 \mathrm{~mL}$ of spoil and $200 \mathrm{~mL}$ of sphagnum peat moss (Premier Horticulture Inc., Redhill, PA). The coco peat treatment consisted of $200 \mathrm{~mL}$ of spoil and $200 \mathrm{~mL}$ of coco peat (Sunleaves Garden Products, Bloomington, IN). The sewage sludge treatment consisted of $200 \mathrm{~mL}$ of spoil and $200 \mathrm{~mL}$ of sludge. Equivalent field application rates for peat moss, coco peat, and sludge amendments were 17.78 $\mathrm{Mg} \mathrm{ha}^{-1}, 11.11 \mathrm{Mg} \mathrm{ha}^{-1}$, and $9.37 \mathrm{Mg} \mathrm{ha}^{-1}$, respectively. Ten replicates of each treatment were used for each species for a total of 160 pots.

\section{Growth/Harvest}

Planting occurred on January 26, 2012. Seeds of wild lupine and Illinois bundleflower were scarified with sandpaper and inoculated with Rhizobium spp. bacteria prior to planting. Rhizobium stimulates legume growth through nitrogen fixation, especially in dune ecosystems, and therefore should also be added in field applications of sand mine restoration (Van Der Heijden et al. 2006). Wild lupine seeds were cold-moist stratified for 3 days at $4^{\circ} \mathrm{C}$ in a $50 / 50 \mathrm{mix}$ of damp sand/seed prior to planting. Seeds of Indian grass and little bluestem did not receive any treatment prior to planting. Seeds of all species were obtained from Prairie Moon Nursery, Winona, MN. Five seeds of each species were planted at a depth of $1 \mathrm{~cm}$ in each pot. Pots were placed on tables in a greenhouse at Grand Valley State University, Allendale, MI.

Each pot was watered every other day and received a total of $105 \mathrm{~mL}$ water/week. Natural sunlight was supplemented with fluorescent grow lights to provide a total of 14 hours of sunlight/day. The watering rate corresponds to the average weekly rainfall between April and August in Ottawa County, MI., while light exposure corresponds to the average day length between April and May in the area (Pregitzer 1972). The location of each pot was randomized throughout the greenhouse tables after each watering. The greenhouse was maintained at $22-24^{\circ} \mathrm{C}$ throughout the experiment.

Plants were harvested on April 5, 2012. Extraction involved gently prying the plant and root ball from the spoil with the aid of a spoon. Roots were then rinsed with deionized water. After extraction, roots and shoots were separated, dried at $65^{\circ} \mathrm{C}$ to a constant weight, and weighed. 
Table 1. Mean germination ( $\% \pm 1 \mathrm{SE}$ ) among species and spoil amendment treatments. Each treatment contained a mixture of $200 \mathrm{~mL}$ of the amendment and $200 \mathrm{~mL}$ of spoil. The control treatment consisted of $400 \mathrm{~mL}$ of spoil only. Species in the sludge treatment did not exhibit any germination. Mean values with different superscript letters in the overall column indicate a significant difference between species at $p<0.050$. Mean values with different superscript letters across a row indicates a significant difference between treatments for a species at $p<0.050$.

\begin{tabular}{lccccc}
\hline Species & Overall & Control & Peat & Sludge & Coco peat \\
\hline Lupinus perennis & $33 \% \pm 4.6^{\mathrm{a}}$ & $24 \% \pm 6.5^{\mathrm{a}}$ & $48 \% \pm 8.0^{\mathrm{b}}$ & $0 \% \pm 0^{\mathrm{c}}$ & $58 \% \pm 6.3^{\mathrm{b}}$ \\
Desmanthus illinoensis & $46 \% \pm 5.3^{\mathrm{a}}$ & $72 \% \pm 6.8^{\mathrm{a}}$ & $44 \% \pm 6.5^{\mathrm{b}}$ & $0 \% \pm 0^{\mathrm{c}}$ & $68 \% \pm 6.1^{\mathrm{a}}$ \\
Schizachyrium scoparium & $2 \% \pm 1.0^{\mathrm{b}}$ & $2 \% \pm 2.0$ & $4 \% \pm 2.7$ & $0 \% \pm 0$ & $2 \% \pm 2.0$ \\
Sorghastrum nutans & $3 \% \pm 1.1^{\mathrm{b}}$ & $2 \% \pm 2.0$ & $2 \% \pm 2.0$ & $0 \% \pm 0$ & $6 \% \pm 3.1$ \\
All species combined & $21 \% \pm 2.3$ & $25 \% \pm 5.2$ & $25 \% \pm 4.3$ & $0 \% \pm 0$ & $34 \% \pm 5.3$ \\
\hline
\end{tabular}

\section{Data Analysis}

Percent germination was calculated as the total number of seedlings per pot divided by the number of seeds planted. Mean root, shoot, and total live weight were calculated as the total weight per pot divided by the number of seedlings within each pot. A three-way analysis of variance (ANOVA) was conducted using treatment, species, and number of seedlings as main effects and root, shoot and total biomass as the response. Tukey's honest significant difference test (HSD) was used for post-hoc comparisons of significant ANOVA analyses. Non-parametric statistical tests were used for data that did not meet assumptions of parametric statistical analysis, despite several attempts at transformation. Specifically, Kruskal-Wallis tests were used to examine differences in germination among treatments and species. Significant Kruskal-Wallis tests were followed by Mann-Whitney $U$ tests to examine differences between species and treatments. SPSS 19.0 was used for all statistical analyses (SPSS v. 19.0 for Windows, IBM, Inc., Chicago IL).

\section{Results}

Germination differed significantly among all species when all treatments were combined (Kruskal-Wallis $\chi^{2}=67.345$, $\mathrm{df}=3, p<0.001)$. Illinois bundleflower exhibited the greatest mean germination rate at $46 \%$ followed by wild lupine at $33 \%$. Germination for both of these species was significantly greater than both grass species $(p<0.001$; Table 1). Seedling density did not significantly impact root, shoot, or total biomass, nor were there significant interactions between seedling density and treatment or seedling density and species. However, shoot and total biomass differed significantly among species (ANOVA; Shoot: $\mathrm{F}=$ 2.904, $\mathrm{df}=3,65, p<0.050$; Total biomass: $\mathrm{F}=3.511, \mathrm{df}=$ $3,65, p<0.050)$.

Comparisons among species show that lupine exhibited the highest overall mean root, shoot, and total biomass per plant. Mean shoot biomass at $0.067 \mathrm{~g}$ was significantly greater than shoot biomass of Illinois bundleflower $(p<$ 0.050 ). Mean total biomass at $0.082 \mathrm{~g}$ was significantly greater than total biomass of all other species $(p<0.050$; Table 2).

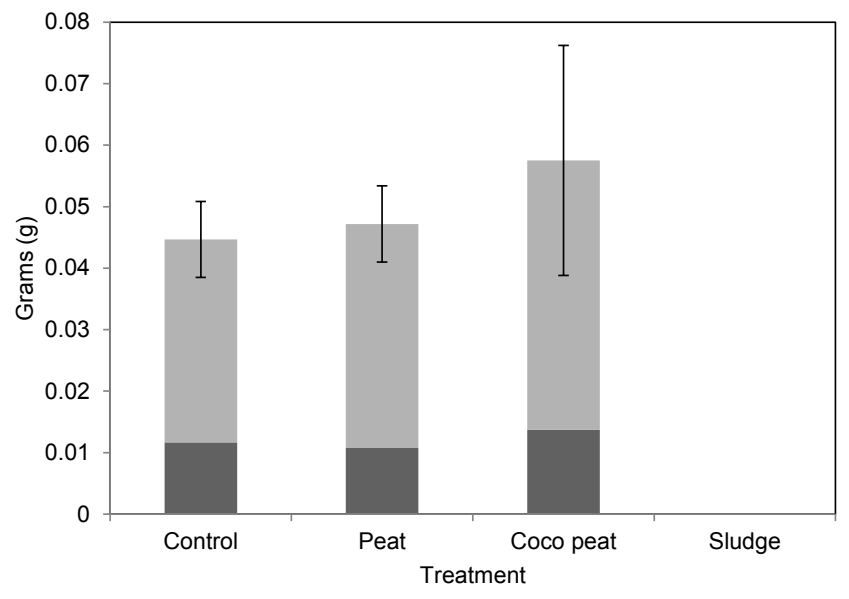

Figure 1. Mean root, shoot, and total biomass per plant ( $g \pm 1 \mathrm{SE}$ ) among spoil amendment treatments for all species combined. Light gray indicates shoot weight; Dark gray indicates root weight. Each treatment contained a mixture of $200 \mathrm{~mL}$ of the amendment and $200 \mathrm{~mL}$ of spoil. The control treatment consisted of $400 \mathrm{~mL}$ of spoil only. Species in the sludge treatment did not exhibit any growth.

Comparisons among treatments show that the addition of coco peat to spoil had a positive effect on germination and biomass accumulation. Mean germination was greatest with coco peat at $34 \%$, but this result was not significantly different than germination success in the peat or control treatments (mean $=25 \%$ in each treatment; Table 1). Similarly, mean root, shoot, and total biomass per plant was greatest with the addition of coco peat, however, results were not significantly different among treatments. Conversely, the addition of sewage sludge prohibited seed germination, and therefore growth, of all species (Table 1; Figure 1).

Germination and growth differed among spoil treatments for lupine. The addition of coco peat positively affected germination of lupine; mean seed germination was $58 \%$ with coco peat and $24 \%$ in the control (Mann-Whitney $\mathrm{U}=12.5, p<0.010)$. Similarly, total growth of lupine was greatest with coco peat (mean $=0.097 \mathrm{~g}$ ), however, this result was not significantly greater than the impact of other spoil treatments on lupine growth (Table 2). Peat also had a significantly positive affect on lupine germination 
Table 2. Mean root, shoot, and total biomass per plant ( $\mathrm{g} \pm 1 \mathrm{SE}$ ) among species and spoil amendment treatments. Each treatment contained a mixture of $200 \mathrm{~mL}$ of the amendment and $200 \mathrm{~mL}$ of spoil. The control treatment consisted of $\mathbf{4 0 0} \mathrm{mL}$ of spoil only. Species in the sludge treatment did not exhibit any growth. Mean values with different superscript letters among biomass subcategories in the overall column indicate a significant difference between species at $p<0.050$.

\begin{tabular}{llccccc}
\hline Species & & Overall & Control & Peat & Sludge & Coco peat \\
\hline Lupinus perennis & Root & $0.015 \pm 0.001$ & $0.016 \pm 0.004$ & $0.015 \pm 0.002$ & $\mathrm{~N} / \mathrm{A}$ & $0.014 \pm 0.001$ \\
& Shoot & $0.067 \pm 0.016^{\mathrm{a}}$ & $0.056 \pm 0.006$ & $0.057 \pm 0.006$ & $\mathrm{~N} / \mathrm{A}$ & $0.084 \pm 0.041$ \\
& Total & $0.082 \pm 0.016^{\mathrm{a}}$ & $0.072 \pm 0.008$ & $0.072 \pm 0.006$ & $\mathrm{~N} / \mathrm{A}$ & $0.097 \pm 0.042$ \\
Desmanthus illinoensis & Root & $0.013 \pm 0.003$ & $0.011 \pm 0.001$ & $0.008 \pm 0.001$ & $\mathrm{~N} / \mathrm{A}$ & $0.019 \pm 0.009$ \\
& Shoot & $0.023 \pm 0.002^{\mathrm{b}}$ & $0.022 \pm 0.001$ & $0.025 \pm 0.006$ & $\mathrm{~N} / \mathrm{A}$ & $0.021 \pm 0.003$ \\
& Total & $0.035 \pm 0.004^{\mathrm{b}}$ & $0.033 \pm 0.002$ & $0.033 \pm 0.007$ & $\mathrm{~N} / \mathrm{A}$ & $0.040 \pm 0.008$ \\
Schizachyrium scoparium & Root & $0.001 \pm 0.001$ & 0.001 & $0.002 \pm 0.001$ & $\mathrm{~N} / \mathrm{A}$ & 0.001 \\
& Shoot & $0.004 \pm 0.003$ & 0.002 & $0.007 \pm 0.006$ & $\mathrm{~N} / \mathrm{A}$ & 0.001 \\
& Total & $0.006 \pm 0.003^{\mathrm{b}}$ & 0.003 & $0.009 \pm 0.007$ & $\mathrm{~N} / \mathrm{A}$ & 0.002 \\
Sorghastrum nutans & Root & $0.003 \pm 0.002$ & 0.002 & 0.011 & $\mathrm{~N} / \mathrm{A}$ & $0.001 \pm 0.000$ \\
& Shoot & $0.008 \pm 0.004$ & 0.008 & 0.024 & $\mathrm{~N} / \mathrm{A}$ & $0.002 \pm 0.001$ \\
& Total & $0.011 \pm 0.006^{\mathrm{b}}$ & 0.010 & 0.035 & $\mathrm{~N} / \mathrm{A}$ & $0.003 \pm 0.001$ \\
\hline
\end{tabular}

compared to the control (Mann-Whitney $U=23.0, p$ $<0.050)$. Germination of lupine was significantly lower with the addition of sludge compared to all other spoil treatments $(p<0.010$; Table 1$)$.

Mean germination of Illinois bundleflower was highest in the control treatment which was significantly greater than germination in the peat treatment ( $72 \%$ vs. $44 \%$, respectively; Mann-Whitney $U=18.0, p<0.050)$. The second highest germination rate was in the coco peat treatment (68\%) which was also significantly greater than germination in the peat treatment (Mann-Whitney $\mathrm{U}=$ $20.5, p<0.050)$. Germination of Illinois bundleflower was significantly lower with the addition of sludge compared to all other spoil treatments $(p<0.010$; Table 1$)$. Total growth of Illinois bundleflower was greatest with the addition of coco peat $($ mean $=0.040 \mathrm{~g})$, however, this result was not significantly greater than the impact of other spoil treatments on bundleflower growth (Table 2).

Germination and growth of little bluestem and Indian grass was not significantly different with the addition of any spoil amendment. Mean germination was low for both little bluestem and Indian grass in all spoil treatments (Table 1). Similarly, root, shoot, and total growth were low for these species regardless of treatment (Table 2).

\section{Discussion}

We recommend wild lupine as a potential candidate for the reclamation of sand mines. Lupine exhibited greater growth than all other species and the second highest germination success rate at $33 \%$. Though germination success for lupine was greater in this study compared to previous research ( 21\%; Aschenbach et al. 2012), both are still considerably lower than germination success observed in field trials ( 80\%; St. Mary 2007, Pavlovic and Grundel 2009). Therefore, wild lupine may exhibit better establishment success in a sand reclamation application than in the greenhouse environment employed here.

Lupine's ability to fix atmospheric nitrogen contributes to the establishment success of other species used in sand mine reclamation. Soil nitrogen deficiency is a major factor limiting plant growth on spoils produced from the extraction of minerals. In nutrient poor soils, legumes have been shown to perform well when compared to non-legume species (Elias and Chadwick 1979, Imsande and Touraine 1994). Legume growth on sandy soils increases the amount of plant-available nitrogen $\left(\mathrm{NH}_{4}^{+}\right.$and $\left.\mathrm{NO}_{3}^{-}\right)$up to $250 \mathrm{~kg} /$ ha per year, via nitrogen fixation and leaf decomposition, and in return promotes the establishment and growth of other plant species (Dancer et al. 1977, Jefferies et al. 1981). Morris and Wood (1989) found that non-leguminous seedlings that established in the presence of Lupinus lepidus exhibited greater growth and flowering probability than in bare patches.

Our recommendation to use lupine in sand mine reclamation efforts should be considered in light of its limitations. Lupine requires high amounts of sunlight and performs poorly in low-light environments. When provided insufficient sunlight, lupine exhibits lower abundance, growth, survival, and rates of nitrogen fixation (Smallidge et al. 1996, Grundel et al. 1998, Pavlovic and Grundel 2009). In high soil nitrogen environments, legumes exhibit reduced nitrogen-fixing abilities (Lang et al. 1993, Rubio Arias et al. 1999) which would limit the facilitative effect of lupine with spoil amendments such as sludge.

Lupine may also have negative impacts on a plant community. Congeners of wild lupine (i.e., L. arboreus and L. lepidus) were found to inhibit the growth of other species through shading and inhibition of seedling establishment (Morris and Wood 1989). Therefore, management such as burning or mowing regimes may be required to reduce its competitive effect on other plants (Gosling 2005). Due to its 
ability to increase soil nitrogen, wild lupine has the potential to degrade plant community diversity by facilitating the establishment of invasive or undesirable plant species (Maron and Connors 1996, Lozon and MacIsaac 1997).

We also recommend Illinois bundleflower as a candidate species for the reclamation of sand mines. Illinois bundleflower exhibited the greatest germination success (46\%) and relatively high growth overall. Among spoil amendments, germination was significantly greater for Illinois bundelflower in the control than in the peat amended spoil, suggesting that Illinois bundleflower would be a good candidate for revegetation where spoil amendment is impractical. A similar study found that overall germination success for Illinois bundleflower was slightly lower under greenhouse conditions ( 40\%; Aschenbach et al. 2012). Other researchers have observed much higher germination success in laboratory settings (i.e., 96\%; Call 1985), while others have observed lower germination success in field trials (i.e., 4-44\%; Dovel et al. 1990). This high variability in germination success suggests that site-specific evaluation may be necessary prior to large-scale revegetation efforts. Like lupine, Illinois bundleflower exhibits the ability to fix atmospheric nitrogen. Nitrogen fixation can facilitate the establishment of other non-legumes in low nutrient environments such as those found in former sand mines (Crocker and Major 1955).

Although both warm-season grasses performed best in the peat moss treatment, neither exhibited high rates of germination or growth. The lack of germination in the sludge treatment may be due to undesirable salinity or $\mathrm{pH}$ levels. Electrical conductivity was $27.83 \mathrm{dS} / \mathrm{m}$ in the sludge treatment. While successful growth of native grass transplants has been shown at salinity levels above $57 \mathrm{dS} / \mathrm{m}$ (Aschenbach 2006), the electrical conductivity in the sludge treatment is well above the $15-20 \mathrm{dS} / \mathrm{m}$ threshold that constrains germination in non-halophytic plants (Larcher 1995). Soil pH of $\geq 5.5$ is recommended for optimal growth of warm-season grasses (Dickerson et al. 1998); spoil amended with sludge exhibited a mean $\mathrm{pH}$ of 4.9.

Soil nitrate levels in our spoil treatments were between 1.9 and $341.9 \mathrm{mg} / \mathrm{kg}$ which are appropriate for successful growth of warm-season grasses. Although warm-season grasses have been shown to respond positively to soil nitrogen levels that are similar or greater than the levels observed in this experiment (e.g., 181-1060 mg/kg; Tilman and Wedin 1991), successful grass establishment has also been observed at soil nitrate levels that are much lower than the levels observed here (e.g., $0.8 \mathrm{mg} / \mathrm{kg}$; Gillen and Berg 1998).

Though the warm-season grasses performed poorly in this experiment, they should still be considered for use in revegetating former sand mines. Gaffney and Dickerson (1987) found that over an 8-year period, warm-season grasses were the most successful in revegetating former sand mines when compared to legumes and cool-season grasses. MacDonald and others (2003) found that it took several years for warm-season grasses to become a dominant component of the plant community. Grasses are also crucial for successful prescribed fire management in that a significant proportion of grasses are necessary for facilitating prescribed fires in plant community restoration projects (Packard and Mutel 1997). Furthermore, bunch grasses are effective barriers against soil erosion and having a mixture of grasses and forbs helps to promote biodiversity on the site (Tilman and Haddi 1992, Dabney et al. 1993, Dewald et al. 1996).

Among spoil amendments, coco peat exhibited the greatest positive effect on germination and root, shoot, and total biomass. Coco peat had a significant positive effect on the germination of lupine, and it also positively affected the growth of lupine and Illinois bundleflower. The impact of coco peat on germination and growth could be attributed to its ability to improve spoil water holding capacity and porosity (Khayyat et al. 2007, Awang et al. 2009). Coco peat also has been found to introduce increased amounts of potassium into the soil (Treder 2008). Although coco peat slightly increased mean spoil acidity, it did not change acidity beyond the tolerable range for most vascular plants (i.e., pH 3.5-8.5; Larcher 1995). In general, the addition of organic matter also lowers the bulk density of the soil and increases its ability to resist compaction, which may also aid in plant growth and germination (Benigno et al. 2013). Furthermore, the use of coco peat in combination with other soil amendments greatly improves soil characteristics and the effectiveness of coco peat. For example, drainage, aeration, bulk density, electrical conductivity, and overall plant growth were improved when coco peat was combined with burnt rice hulls (Awang et al. 2009). Similarly, Khayyat and others (2007) observed an increase in root number, length, and weight when coco peat was used in combination with peat moss or sand.

The spoil amended with peat moss had increased rates of germination and growth compared to the sludge or control treatments. Sand mine spoil amended with peat moss and a peat moss and fertilizer combination has been shown to have a positive effect on the germination and growth of wild lupine, Illinois bundleflower, and little bluestem (Aschenbach et al. 2012). The improved success of plants in spoil amended with peat moss could be attributed to the increase in soil porosity and water holding capacity, as well as increased soil acidity when peat is added to the spoil (Sjors 1980, Ling et al. 2005, Boyer et al. 2012)

Although our results indicate that peat moss is a useful spoil amendment for promoting the initial establishment and growth of plants when revegetating former sand mines, we do not recommend peat due to its negative environmental effects. Globally, peat bogs have been destroyed due to peat harvest, which has negative long-term impacts on the regional plant and animal diversity (Rochefort 2000, 
Mitchell et al. 2002, Suret et al. 2002). Peatlands are importers of $\mathrm{CO}_{2}$ and represent a major global pool of sequestered carbon (Gorham 1991). Peat mining decreases carbon sequestration capacity by up to $37 \%$ and transforms these areas from carbon sinks to carbon sources (Heathwaite 1993, Cleary et al. 2005). Conversely, coco peat is an abundant agricultural by-product that improves soil quality in a similar fashion to peat moss (Awang et al. 2009), yet does not promote the destruction of peat ecosystems. Therefore, we recommend coco peat as a preferable spoil amendment for restoring former sand mines.

Although the application of municipal sewage sludge can improve soil conditions (Carabassa et al. 2010, Li et al. 2013), we did not observe any germination success for any seeds sown in the spoil amended with sludge. Our lack of success with the sewage sludge amendment may be due to a combination of unfavorable abiotic and biotic soil conditions found in this treatment. Electrical conductivity in the sludge treatment at $27.83 \mathrm{dS} / \mathrm{m}$ is well above the $15-20 \mathrm{dS} / \mathrm{m}$ threshold that constrains germination in nonhalophytic plants (Larcher 1995). The sludge treatment also had the highest acidity $(\mathrm{pH}=4.9)$ compared to all other treatments. Though the $\mathrm{pH}$ is within the favorable range of vascular plants, it is approaching the low-end threshold that may constrain growth $(\mathrm{pH}=3.5$; Larcher 1995). The addition of liming material to this treatment would help to ameliorate adverse impacts due to soil acidity.

Toxic levels of trace elements found in sludge could negatively affect plant growth (Haering et al. 2000). However, we do not think this is the cause for the lack of seed germination in the sludge treatment. The sludge used in this experiment contains trace elements that are below levels that would cause phytotoxicity (Haering et al. 2000, S. Kunst, Grandville Clean Water Plant, unpub. data) and is used extensively for local agricultural applications without adverse impacts to crops (S. Kunst, Grandville Clean Water Plant, pers. comm.).

$\mathrm{Li}$ and others (2013) found an increase in microbial activity with the addition of sewage sludge. Excessive sludge can also inhibit nutrient mineralization and should only be used when the substrate has an organic content of less than $20 \mathrm{~g} / \mathrm{kg}$ (Chander and Brookes 1993, Alcañiz et al. 2008). The non-amended spoil used in this experiment had an organic matter content of $0.4 \%$, which is well below the recommendation by Alcañiz and others (2008). Therefore, municipal sewage sludge should not be ruled out as a possible spoil amendment for use in sand mine reclamation. However, our results and recommendations by other researchers (e.g., MacDonald et al. 2003) suggest that sludge may be best applied after germination and initial plant establishment at rates that do not create adverse soil conditions such as excessive salinity.

We recognize that it may be impractical to improve soil conditions with addition of spoil amendments in every sand mine restoration project. Therefore, it is important to consider species that perform well in non-amended spoil. To this end, we further recommend wild lupine as a primary candidate for sand mine revegetation efforts because it exhibits positive growth responses in the absence of spoil amendments. We also recommend Illinois bundleflower based on similar results in non-amended spoil.

Our recommendations resulting from this study should be viewed within the limitations of this experiment. We evaluated seedling establishment under greenhouse conditions. We would expect to observe different results had this experiment been carried out under field conditions with a longer period of growth. For example, we found that legumes exhibited the greatest initial growth when compared to warm-season grasses. Conversely, other researchers working with little bluestem and Indian grass under field conditions found that these species eventually become dominant components of the plant community (Dickerson et al. 1998). We also chose to use only one spoil:amendment ratio for this experiment, but other studies have found that these amendments can have varying effects on plant growth depending on the specific ratio used (Khayyat et al. 2007, Awang et al. 2012, Li et al. 2013). Our greenhouse experiment allowed us to control for variables such as water availability, seed density, seed predation, herbivory, intraand interspecific competition. While it may be difficult to control these variables under field conditions, a practitioner can help alleviate some of the potential problems associated with these factors. For example, a practitioner could incorporate artificial irrigation, seedling protection from herbivores, and site preparation and management to help reduce interspecific competition.

We also note the limitation of our recommendation of specific species. For example, Illinois bundleflower and Indian grass are not typically found in sand dune habitats (Kost et al. 2010). Although, these species provide erosion control, soil nitrogen, and organic matter additions which can facilitate future colonization of more characteristic species, they would not satisfy restoration goals where only species that are characteristic of sand dune plant communities are acceptable. We also do not recommend establishing monospecific stands of any of these species. Instead, our species recommendations should be considered as potential components of a diverse native species mix.

Despite these limitations, our results are helpful in determining which species and amendment combinations are useful candidates for revegetating former sand mines or similar habitats. We further recognize the importance of incorporating coco peat into mine spoils to help improve the water-soil interactions and spoil fertility, thus aiding in the revegetation and restoration efforts of degraded post-sand mining sites. 


\section{Acknowledgements}

We thank Alan Slater of Standard Sand Co., Fairmont Minerals for his support in making this project possible. Todd Wibright and Scott Kunst of the Grandville Clean Water Plant provided sewage sludge for the experiment. We also thank Diane Laughlin and Star Santiago of the Department of Biology, Grand Valley State University (GVSU) for greenhouse assistance. Richard Rediske of GVSU-Annis Water Resources Institute conducted soil analyses. Neil MacDonald provided valuable comments on an earlier draft of this manuscript. We also thank the anonymous reviewers for their insightful comments on this manuscript. Funding for this study was provided by the Jimmy F. New Foundation.

\section{References}

Albert, D.A. 2000. Borne of the wind: An introduction to the ecology of Michigan sand dunes. Lansing MI: Michigan Natural Features Inventory.

Alcañiz, J.M., O. Ortiz and V. Carabassa. 2008. Utilització de fangs de depuradora en restauració. Manual d'aplicació en activitats extractives i terrenys marginals. Agència Catalana de l'AiguaGeneralitat de Catalunya, Barcelona, Spain.

Aschenbach, T.A. 2006. Variation in growth rates under saline conditions between Pascopyrum smithii (western wheatgrass) and Distichlis spicata (inland saltgrass) from Kansas and Nebraska for use in the restoration of salt-affected plant communities. Restoration Ecology 14:21-27.

Aschenbach, T.A., E. Brandt, M. Buzzard, R. Hargreaves, T. Schmidt and A. Zwagerman. 2012. Initial plant growth in sand mine spoil amended with peat moss and fertilizer under greenhouse conditions: Potential species for use in reclamation. Ecological Restoration 30:50-58.

Awang Y., A.S. Shaharom, R.B. Mohamad and A. Selamat. 2009. Chemical and physical characteristics of cocopeat-based media mixtures and their effects on the growth and development of Celosia cristata. American Journal of Agricultural and Biological Sciences 4:63-71.

Benigno, S.M., K.W. Dixon and J.C. Stevens. 2013. Increasing soil water retention with native sourced mulch improves seedling establishment in postmine Mediterranean sandy soils. Restoration Ecology 21:617-626.

Binkley, D. and P. Vitousek. 1991. Soil Nutrient Availability. Pages 75-96 in W. Pearcy, J. Ehleringer, H.A. Mooney and P.W. Rundel (eds), Plant Physiological Ecology: Field Methods and Instrumentation. London, UK: Chapman and Hall.

Bowles, M.L., M.M. Demauro, N.B. Pavlovic and R.D. Hiebert. 1990. Effects of anthropogenic disturbances on endangered and threatened plants at the Indiana Dunes National Lakeshore. Natural Areas Journal 10:187-200.

Boyer, C.R., A. Torbert, C.H. Gilliam, G.B. Fain, T.V. Gallagher and J.L. Sibley. 2012. Nitrogen immobilization in plant growth substrates: Clean chip residual, pine bark, and peatmoss. International Journal of Agronomy 2012:1-8.

Call, C.A. 1985. Storage life of Illinois Bundleflower and Western Indigo seed. Journal of Range Management 38:500-503.

Callaway, R.M. 1995. Positive interactions among plants. Botanical Review 61:306-349.

Callaway, R.M and L.R. Walker. 1997. Competition and facilitation: A synthetic approach to interactions in plant communities. Ecology 78:1958-1965.
Carabassa, V., E. Serra, O. Ortiz and J.M. Alcañiz. 2010. Sewage sludge application protocol for quarry restoration (Catalonia). Restoration Ecology 28:420-422.

Carson, W.P. and G.W. Barrett. 1988. Succession in old-field plant communities: Effects of contrasting types of nutrient enrichment. Ecology 69:984-994.

Chander, K. and P.C. Brookes. 1993. Is the dehydrogenase assay invalid to estimate microbial activity in copper-contaminated soils? Soil Biology \& Biochemistry 25:1231-1239.

Choi, Y.D. and N.B. Pavlovic. 1998. Experimental restoration of native vegetation in Indiana Dunes National Lakeshore. Restoration Ecology 6:118-129.

Cleary, J., N.T. Roulet and T.R. Moore. 2005. Greenhouse gas emissions from Canadian peat extraction, 1990-2000: A life-cycle analysis. Ambio 34:456-461.

Cole, K.L., M.B. Davis, F. Stearns, G. Guntenspergen and K. Walker. 1998. Historical land cover changes in the Great Lakes Region. Perspectives on the Land use History of North America 6:43-50.

Crocker, R.L. and J. Major. 1955. Soil development in relation to vegetation and surface age at Glacier Bay, Alaska. Journal of Ecology 43:427-448.

Cummings, J., N. Reid, I. Davies and C. Grant. 2005. Adaptive restoration of sand-mined areas for biological conservation. Journal of Applied Ecology 42:160-170.

Curtis, M.J. and V.P. Claassen. 2009. Regenerating topsoil functionality in four drastically disturbed soil types by compost incorporation. Restoration Ecology 17:24-32.

Dabney, S.M., K.C. McGregor, L.D. Meyer, E.H. Grissinger and G.R. Foster. 1993. Vegetative barriers for runoff and sediment control. Pages 60-70 in J.K. Mitchell (ed), Integrated Resource Management and Landscape Modification for Environmental Protection. St. Joseph, MI: American Society of Agricultural Engineers.

Dancer, W.S., J.F. Handley and A.D. Bradshaw. 1977. Nitrogen accumulation in kaolin mining wastes in Cornwall. Plant and Soil 48:303-314.

Dewald, C.L., J. Henry, S. Bruckerhoff, J. Ritchie, S. Dabney, D. Shepherd, J. Douglas and D. Wolf. 1996. Guidelines for establishing warm season grass hedges for erosion control Journal of Soil and Water Conservation 51:16-20.

Dickerson, J.D., D.B. Wark, D. Burgdorf, R. Maher, T. Bush, B. Poole and C. Miller. 1998. Vegetating with Native Grasses in Northeastern North America: A Manual. Syracuse NY: U.S. Department of Agriculture Natural Resources Conservation Service Plant Materials Program and Ducks Unlimited Canada.

Dovel, R.L., M.A. Hussey and E.C. Holt. 1990. Establishment and survival of Illinois Bundleflower interseeded into an established kleingrass pasture. Journal of Range Management 43:153-156.

Elias, C.O. and M.J. Chadwick. 1979. Growth characteristics of grass and legume cultivars and their potential for land reclamation. Journal of Applied Ecology 16:537-544.

Enright, N. and B.B. Lamont. 1992. Survival, growth, and water relations of Banksia seedlings on a sand mine rehabilitation site and adjacent scrub-health sites. Journal of Applied Ecology 29:663-671.

Fierro, A., D.A. Angers and C.J. Beauchamp. 1999. Restoration of ecosystem function in an abandoned sandpit: Plant and soil responses to paper de-inking sludge. Applied Ecology 36:244-253.

Gaffney, F.B. and J.A. Dickerson. 1987. Species selection for revegetating sand and gravel mines in the Northeast. Journal of Soil and Water Conservation 42:358-361. 
Gillen, R.L. and W.A. Berg. 1998. Nitrogen fertilization of a native grass planting in western Oklahoma. Journal of Range Management 51:436-441.

Gosling, P. 2005. Facilitation of Urtica dioica colonization by Lupinus arboreus on a nutrient poor mining spoil. Plant Ecology 178: 141-148.

Gorham, E. 1991. Northern peatlands role in the global carbon cycle and probable responses to climatic warming. Ecological Applications 1:182-195.

Grundel, R., N.B. Pavlovic and C.L. Sulzman. 1998. The effect of canopy cover and seasonal change on host plant quality for the endangered Karner blue butterfly (Lycaeides Melissa samuelis). Oecologia 114:243-250.

Haering, K.C., W.L. Daniels and S.E. Feagley. 2000. Reclaiming mined lands with biosolids, manures, and papermill sludges. Pages 615644 in R.I. Barnhisel, R.G. Darmody and W.L. Daniels (eds), Reclamation of Drastically Disturbed Lands. Madison, WI: American Society of Agronomy, Crop Science Society of America, and Soil Science Society of America.

Hamzé, S.I. and C.L. Jolls. 2000. Germination ecology of a federally threatened endemic thistle, Cirsium pitcheri, of the Great Lakes. The American Midland Naturalist 143:141-153.

Heathwaite, A.L. 1993. Disappearing peat-regenerating peat? The impact of climate change on British peatlands. Geographical Journal 159:203-208.

Imsande, J. and B. Touraine. 1994. $\mathrm{N}$ demand and the regulation of nitrate uptake. Plant Physiology 105:3-7.

Jefferies, R.A., A.D. Bradshaw and P.D. Putwain. 1981. Growth, nitrogen accumulation and nitrogen transfer by legume species established on mine spoils. Applied Ecology 18:945-956.

Khayyat, M., F. Nazari, and H. Salehi. 2007. Effects of different pot mixtures on pothos (Epipremnum aureum Lindl. And Andre 'Golden Pothos') growth and development. American-Eurasian Journal of Agricultural and Environmental Science 2:341-348.

Kost, M.A., D.A. Albert, J.G. Cohen, B.S. Slaughter, R.K. Schillo, C.R. Weber and K.A. Chapman. 2010. Natural communities of Michigan: Classification and description. Report No. 2007-21, vers. 1.2. Lansing, MI: Natural Features Inventory.

Lake Michigan Federation. 1999. Vanishing Lake Michigan Sand Dunes: Threats from Mining. Muskegon, MI: Lake Michigan Federation.

Lang, P., R. Martin and M.P. Golvano. 1993. Effect of nitrate on carbon metabolism and nitrogen fixation in root nodules of Lupinus albus. Plant Physiology and Biochemistry31:639-648.

Larcher, W. 1995. Physiological Plant Ecology. Berlin, Germany: Springer.

Larney, F.J. and D.A. Angers. 2012. The role of organic amendments in soil reclamation. Canadian Journal of Soil Science 92:19-38.

Li, S., D. Xiaoyan, D. Wu and J. Zhang. 2013. Effects of sewage sludge and nitrogen fertilizer on herbage growth and soil fertility improvement in restoration of the abandoned opencast mining areas in Shanxi, China. Environmental Earth Sciences 70:3323-3333

Ling, Q., W. Qinping, L. Jiarui, W. Xiaowei and L. Jun. 2005. Effects of peat on water conserving properties of sandy soil. Transactions of the Chinese Society of Agricultural Engineering 21:163-175.

Lozon, J.D. and H.J. MacIsaac. 1997. Biological Invasions: Are they dependent on disturbance? Environmental Reviews 5:131-144.

MacDonald, N.W., M.T. Koetje and B.J. Perry. 2003. Native warmseason grass establishment on spotted knapweed-infested gravel mine spoils. Journal of Soil and Water Conservation 58:243-250.
Maron, J.L. and P.G. Connors. 1996. A native nitrogen-fixing shrub facilitates weed invasion. Oecologia 105:302-312.

Maun, M.A. and I. Krajnyk 1989. Stabilization of Great Lakes sand dunes: Effect of planting time, mulches and fertilizer on seeding establishment. Journal of Coastal Research 5:791-800.

Mitchell, E.A.D., A. Buttler, P. Grosvernier, H. Rydin, A. Siegenthaler and J.M. Gobat. 2002. Contrasted effects of increased N and $\mathrm{CO} 2$ supply on two keystone species in peatland restoration and implications for global change. Journal of Ecology 90:529-533.

Morris W.F. and D.M. Wood. 1989. The role of lupine in succession on Mount St. Helens: Facilitation or inhibition? Ecology 70:697-703.

Nelson, D.W. and L.E. Sommers. 1996. Total carbon, organic carbon, and organic matter. Pages 961-1010 in D.L. Sparks (ed), Methods of Soil Analysis, Part 3, Chemical Methods. Madison, WI: Soil Science Society of America.

Packard, S. and C.F. Mutel. 1997. The Tallgrass Restoration Handbook: For Prairies, Savannas and Woodlands. Washington, DC: Island Press.

Palmgren, G. 2000. Sand mine restoration plan: Grand Mere State Park. Lansing MI: Michigan Department of Natural Resources.

Pavlovic, N.B. and R. Grundel. 2009. Reintroduction of wild lupine (Lupinus perennis L.) depends on variation in canopy, vegetation, and litter cover. Restoration Ecology 17:807-817.

Pichtel, J.R., W.A. Dick and P. Sutton. 1994. Comparison of amendments and management practices for long-term reclamation of abandoned mine lands. Journal of Environmental Quality 23:766-772.

Pregitzer, K.E. 1972. Soil Survey of Ottawa County, Michigan. Washington, DC: U.S. Department of Agriculture Soil Conservation Service.

Prosser, I.P. and S.J. Roseby. 1995. A chronosequence of rapid leaching of mixed podzol soil materials following sand mining. Geoderma 61:297-308.

Reeder, J.D. and B. Sabey. 1987. Nitrogen. Reclaiming mine spoils and overburden in the western United States. Pages 155-184 in R.D.Williams and G.E. Schuman (eds), Analytic Parameters and Procedures. Ankeny, IA: Soil Conservation Society of America.

Rhoades, J.D. 1996. Salinity: Electrical conductivity and total dissolved salts. Pages 417-435 in D.L. Sparks (ed), Methods of Soil Analysis, Part 3-Chemical Methods. Soil Science Society of America Book Series No. 5, Soil Science Society of America and American Society of Agronomy, Madison, WI.

Rochefort, L. 2000. A keystone genus in habitat restoration. The Bryologist 103:503-508.

Rubio Arias, H.O., L. de la Vega, O. Ruiz and K. Wood. 1999. Differential nodulation response and biomass yield of Alexandria clover as affected by levels of inorganic nitrogen fertilizer. Journal of Plant Nutrition 22:1233-1239.

Sjors, H. 1980. Peat on earth: multiple use or conservation. Ambio 9:303-308.

Smallidge, P.J., D.J. Leopold and C.M. Allen. 1996 Community characteristics and vegetation management of Karner blue butterfly (Lycaeidesmelissa samuelis) habitats on rights of-way in eastcentral New York, USA. Journal of Applied Ecology 33:1405-1419.

Spehn, E.M., M. Scherer-Lorenzen, B. Schmid, A. Hector, M.C. Caldeira, P.G. Dimitrakopoulos, J.A. Finn, A. Jumpponen, G. O’Donnovan, J.S. Pereira, E.-D. Schulze, A.Y. Troumbis, and C. Körner. 2002. The role of legumes as a component of biodiversity in a cross European study of grassland biomass nitrogen. Oikos 98:205-218. 
St. Mary, M.K. 2007. A study on the effectiveness of transplanting vs. seeding of Lupinus perennis in an oak savanna regeneration site. M.S. Thesis, Bowling Green State University.

Suret, C., G.L. Brun and V.N. Malet. 2002. Impact of a commercial peat moss operation on water quality and biota in a small tributary of the Richibucto River, Kent County, New Brunswick, Canada. Archives of Environmental Contamination and Toxicology 42:423-430.

Thornton E.B., A. Sallenger, J.C. Sesto, L. Egley, T. McGee and R. Parsons. 2006. Sand mining impacts on long-term dune erosion in Southern Monterey Bay. Marine Geology 229:45-58.

Tilman, D. 1988. Plant Strategies and the Dynamics and Structure of Plant Communities. Princeton, NJ: Princeton University Press.

Tilman, D. and D. Wedin. 1991. Plant traits and resource reduction for five grasses growing on a nitrogen gradient. Ecology 72:685-700.

Tilman, D. and A.E. Haddi. 1992. Drought and biodiversity in Grasslands. Oecologia 89:257-264.

Treder, J.2008. The effects of cocopeat and fertilization on the growth and flowering of oriental lily 'star gazer'. Journal of Fruit and Ornamental Plant Research 16:361-370.

U.S. Department of Agriculture-Natural Resources Conservation Service (USDA-NRCS). 2014. The PLANTS Database. Greensboro, NC: National Plant Data Team. plants.usda.gov

U.S. Department of Health and Human Services (USDHHS). 2008. Sand and Gravel Operator Mining Facts-2006. Publication No. 2008-160. Washington DC: National Institute for Occupational Safety and Health. www.cdc.gov/Niosh/mining/pubs/pdfs/2008160.pdf

U.S. Geological Survey (USGS). 2009. The Mineral Industry of Michigan. Minerals Yearbook. minerals.usgs.gov/minerals/pubs/ state/2009/myb2-2009-mi.pdf.

U.S. Geological Survey (USGS). 2010. Sand and gravel statistics. In T.D. Kelly and G.R. Matos (eds), Historical Statistics for Mineral and Material Commodities in the United States. pubs.usgs.gov/ ds/2005/140/

U.S. Geological Survey. 2013. Mineral commodity summaries 2013: U.S. Geological Survey. 138-139. minerals.usgs.gov/minerals/ pubs/mcs/2013/mcs2013.pdf.

U.S. Lake Survey. 1952. Shoreline of the Great Lakes and Connecting Rivers. File No. 3-3284.

Van Der Heijden, M.G.A, R Bakker, J. Verwaal, T.R. Scheublin, M. Rutten, R. Van Logtestijn and C. Staehelin. 2006. Symbiotic bacteria as a determinant of plant community structure and plant productivity in dune grassland. FEMS Microbiology Ecology 56:178-187.

Wali, M.K. 1999. Ecological succession and the rehabilitation of disturbed terrestrial ecosystems. Plant and Soil 213:195-220.

Wester, D.B., R.E. Sosebee, R.E. Zartman, E.B. Fish, J.C. Villalobos, R. Mata-Gonzalez, P. Jurado and C.A. Moffet. 2011. Biosolids effects in Chihuahuan Desert Rangelands: A ten-year study. Applied and Environmental Soil Science 2011:1-13.

Todd A. Aschenbach (corresponding author), Natural Resources Management Program, Department of Biology, Grand Valley State University, Allendale, MI, USA, 326 Henry Hall 1 Campus Dr., Grand Valley State University, Allendale, MI 49401, aschenbt@gvsu.edu.

Mitchell Poling, Natural Resources Management Program, Department of Biology, Grand Valley State University, Allendale, MI, USA, 326 Henry Hall, 1 Campus Dr., Grand Valley State University, Allendale, MI 49401.

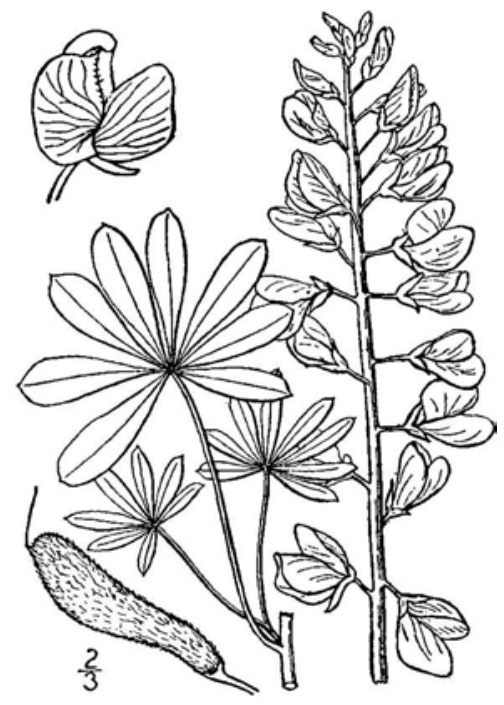

Lupinus perennis. USDA-NRCS PLANTS Database. Britton, N.L. and A. Brown. 1913. An illustrated flora of the northern United States, Canada and the British Possessions. New York, NY: Charles Scribner's Sons. 